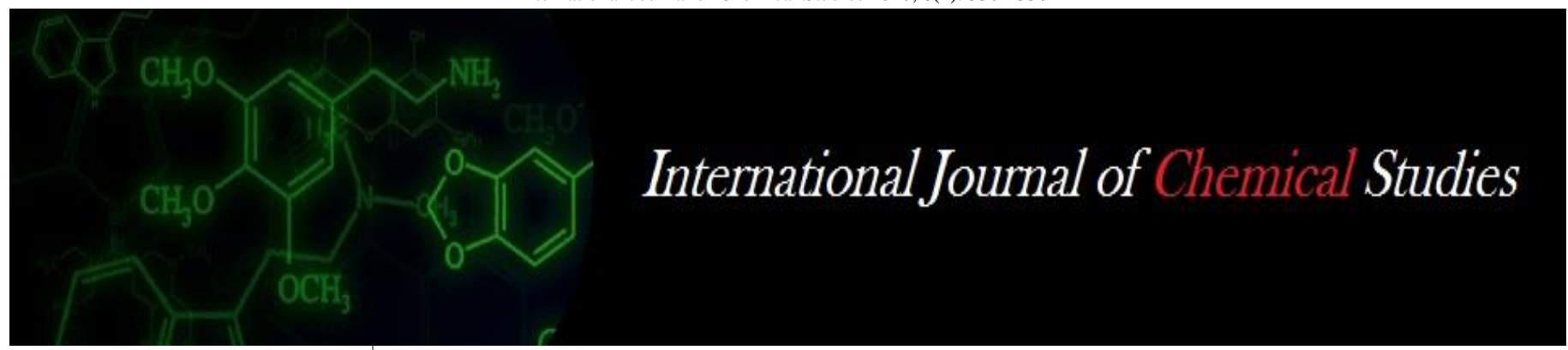

P-ISSN: 2349-8528

E-ISSN: 2321-4902

www.chemijournal.com

IJCS 2020; 8(4): 3502-3504

(C) 2020 IJCS

Received: 02-05-2020

Accepted: 13-06-2020

\section{P Bhavya}

Department of Foods and

Nutrition, Post Graduate \&

Research Centre, PJTS

Agricultural University,

Rajendranagar, Hyderabad,

Telangana, India

S Suchiritha Devi

Department of Foods and

Nutrition, Post Graduate \&

Research Centre, PJTS

Agricultural University,

Rajendranagar, Hyderabad,

Telangana, India

\section{P Janaki Srinath}

Department of Foods and

Nutrition, College of Home

Science, PJTS Agricultura

University, Saifabad,

Hyderabad, Telangana, India

P Sreedevi

Department of Human

Development and Family

Studies, PJTS Agricultural

University, Saifabad,

Hyderabad, Telangana, India

\section{Development sensory evaluation of millet based pizza base}

\section{P Bhavya, S Suchiritha Devi, P Janaki Srinath and P Sreedevi}

\author{
DOI: https://doi.org/10.22271/chemi.2020.v8.i4ar.10193
}

\begin{abstract}
Bakery has been marked the fast-growing industry in food sector over the years. Incorporating the foods that are nutritious and healthy to the individuals was a concern to food industries to develop new products. Pizza was highly consumed and easily acceptable bakery product. Enrichment of pizza can mark the nutritional and health benefits of people. The product millet-based pizza base was developed by incorporating proso millet flour and refined flour in different proportions of 70:30 (PMPB1) and 60:40 (PMPB2) along with control (RFPB) at various temperatures (i.e. $180^{\circ} \mathrm{C}, 190^{\circ} \mathrm{C}, 200^{\circ} \mathrm{C}$ and $205^{\circ} \mathrm{C}$ ). Among these the PMPB1 was selected at $200^{\circ} \mathrm{C}$. The results indicated that the sensory attributes such as texture, taste, crust colour and overall acceptability of developed pizza base was significantly relatable with the control pizza base.
\end{abstract}

Keywords: Pizza base, proso millet flour, refined wheat flour, sensory evaluation

\section{Introduction}

Minor millets are the small seeded with different varieties which includes proso millet (panicum miliaceum), finger millet (eleusine coracana), pearl millet (pennisatum glaucum), kodo millet (paspalum setaceum), foxtail millet (setaria italic), little millet (panicum sumatrense) and barnyard millet (echinochloa utilis). They were known as coarse cereals. (Balasubramanian et al. 2012) ${ }^{[2]}$.

Minor millets which consists of low glycaemic index, low glycaemic load and gluten free content showed that it has many health benefits. It has anticancer, antioxidant, anticholesteremic, anti-hypertensive properties which help in improvement certain disease conditions like cancer, gastro intestinal disorders, atherosclerosis. (Rao and Deepika, 2016) ${ }^{[8]}$. Recent urbanisation has made to increase the demand for the therapeutic bakery products as most of the people are becoming health conscious and with the advancing of many healthrelated conditions. So, there is a need to develop the low cost and therapeutic bakery products with minimum changes in the composition and procedure, yet suitable in the working conditions (Kamaliya, 2000) ${ }^{[4]}$.

Baking is important because several fundamental complex physical processes are coupled during baking, such as, evaporation of water, volume expansion, gelatinization of starch, denaturation of protein and crust formation etc. As soon as the dough is properly baked into bread, a product with superior quality and sensory features occurs. Fresh bread usually presents an appealing brownish and crunchy crust, a pleasant aroma, fine slicing characteristics, a soft and elastic crumb texture, and a moist mouthfeel (Giannou et al. 2003) ${ }^{[3]}$. There has been two-fold increase in the production of bakery products in India during recent years. Increasing growth of fat food companies selling products such as puff, pizza. bread, burger, pastries and hotdog. Along with traditional bakery items like biscuits, cakes, cookies etc has made bakery industry a remarkable place in the of Indian industrial market (Kamliya and Rema, 2003) ${ }^{[5]}$.

Pizza was one of the most commonly purchased items in retail food stores and maintained its market share through the changing nature of the processed food industry and even gained popularity. Pizza was one of the popular consumer foods. It markets in America, Europe and other continents and boosted the trend towards international cuisine and convenience foods. As a result, pizza production has been increased enormously and is expected to increase further in the next decade in relation to growing world population (Preeti and Goyal, 2011) ${ }^{[7]}$.
P Bhavya

Department of Foods and Nutrition, Post Graduate \& Research Centre, PJTS Agricultural University, Rajendranagar, Hyderabad, Telangana, India 


\section{Material and method \\ Raw material}

Proso millet was procured from Millet processing incubation centre, PGRC, Rajendranagar. Refined flour, compressed dry yeast, sugar and other ingredients were procured from local markets of Hyderabad.

\section{Development of pizza base}

According to Kamaliya and Kamaliya (2001) the pizza base (control) was developed using the following ingredients and respective quantities. Thus, incorporating the millet flour and refined flour in different proportions, millet-based pizza base was developed by addition of millet flour along with refined flour and other common ingredients like yeast, sugar, baking powder and salt. Accordingly control pizza base (RFPB) and millet-based pizza base of 70:30 ratio of proso millet flour and refined wheat flour (PMPB1) and 60:40 ratio of proso millet flour and refined wheat flour (PMPB2) was developed at various temperatures as $180^{\circ} \mathrm{C}, 190^{\circ} \mathrm{C}, 200^{\circ} \mathrm{C}$ and $205^{\circ} \mathrm{C}$.

Pizza Base formulations

\begin{tabular}{|c|c|c|c|}
\hline Ingredients & RFPB & PMPB1 & PMPB2 \\
\hline Refined flour (in gms) & $100 \mathrm{~g}$ & $30 \mathrm{~g}$ & $40 \mathrm{~g}$ \\
\hline Proso millet flour (in gms) & - & $70 \mathrm{~g}$ & $60 \mathrm{~g}$ \\
\hline Yeast (g) & 3 & 3 & 3 \\
\hline Sugar (g) & 3 & 3 & 3 \\
\hline Salt (g) & 2 & 2 & 2 \\
\hline Water (ml) & 60 & 55 & 55 \\
\hline
\end{tabular}

\section{Sensory evaluation of pizza base}

The semi trained panel of 15 members from college of community science, saifabad and from Post Graduate and Research Centre, PJTSAU had evaluated the control pizza base (RFPB) along with the millet based pizza base (PMPB1 and PMPB2) for appearance, crust colour, aroma, texture, taste and overall acceptability using the 9 point hedonic scale at different temperatures as $180^{\circ} \mathrm{C}, 190^{\circ} \mathrm{C}, 200^{\circ} \mathrm{C}$ and $205^{\circ} \mathrm{C}$. Scores were based on the 1-9 of hedonic scale, where 1 indicates dislike extremely (very bad) and 9 indicates like extremely (excellent) (Meilgaard et al., 1999) ${ }^{[6]}$.

\section{Statistical analysis of data}

All the results will be analysed to test the significance of the results using percentages, means, standard deviation and analysis of variance (ANOVA) technique. (Snedecor and Cochran, 1983) ${ }^{[9]}$.

\section{Results and discussion}

\section{Sensory evaluation of developed pizza base at $180^{\circ} \mathrm{c}$}

The developed pizza bases PMPB1 of 70:30 proso millet flour and refined wheat flour and PMPB2 of 60:40 proso millet flour and refined wheat flour along with control pizza base (RFPB) baked at $180^{\circ} \mathrm{C}$ were evaluated for sensory scores The appearance for developed pizza base PMPB 1 (7.20 $\pm 0.0 .77)$ at $180^{\circ} \mathrm{C}$ was significantly higher than PMPB2 $(6.66 \pm 0.48)$ and was not on par with the control pizza base $(7.73 \pm 0.70)$. There was a significant difference $(p<0.05)$ between the control and developed pizza bases.

The crust colour showed that the control (RFPB) of 7.66 \pm 0.72 was on par with developed pizza base PMPB1(7.40 \pm 0.63$)$ but not on par with the PMPB2 (7.06 \pm 0.59$)$. Aroma was highest for RFPB (7.46 \pm 0.74$)$ and lowest in the developed pizza base PMPB1 (6.53 \pm 0.74$)$ and PMPB2 (5.46 \pm 0.74$)$.

The texture was higher in RFPB $(7.93 \pm 0.25)$ and lower in the developed pizza bases PMPB1 $(7.40 \pm 0.50)$ and PMPB2 of (6.86 \pm 0.63$)$. The sensory evaluation for taste when evaluated showed that the developed pizza bases PMPB1 (6.53 \pm 0.74$)$ and PMPB2 (5.93 \pm 0.79$)$ was lower when compared to control $(7.93 \pm 0.70)$. There was a significant difference $(p<0.05)$ among the developed pizza base and the control for texture and taste.

The overall acceptability of the developed pizza base PMPB1 $(6.53 \pm 0.70)$ was higher than PMPB2 $(5.93 \pm 0.70)$ but lower than RFPB $(8.26 \pm 0.45)$. There was a significant difference between $(p<0.05)$ between the developed pizza bases and control.

\section{Sensory evaluation of developed pizza base at $190^{\circ} \mathrm{c}$}

The sensory scores for control pizza base RFPB along with PMPB1 and PMPB2 with 70:30 and 60:40 ratio of proso millet flour and refined wheat flour baked at $190^{\circ} \mathrm{C}$ were represented in the Fig: 1.1.1

The appearance, crust color, texture and taste of PMPB1 (7.53,7.80,7.20 and 7.33) and PMPB2 (7.86,7.40,7.46 and 7.20) were correlative baked at $190^{\circ} \mathrm{C}$ but distinct with control pizza base $(8.40,8.40,8.46$ and 8.33$)$. The sensory score of aroma for RFPB (8.20 \pm 0.56$)$ was equivalent with that of PMPB1 $(8.20 \pm 0.63)$ but showed difference in value with PMPB2 (7.40 \pm 0.73$)$. The results manifested that there was a significant difference between the control and developed pizza bases.

The overall acceptability of the developed pizza base PMPB1 (7.26 \pm 0.59$)$ was not on par with PMPB2 $(7.53 \pm 0.83)$ and RFPB (8.33 \pm 0.48$)$. There was a significant difference $(p<0.05)$ between control and the developed pizza bases.

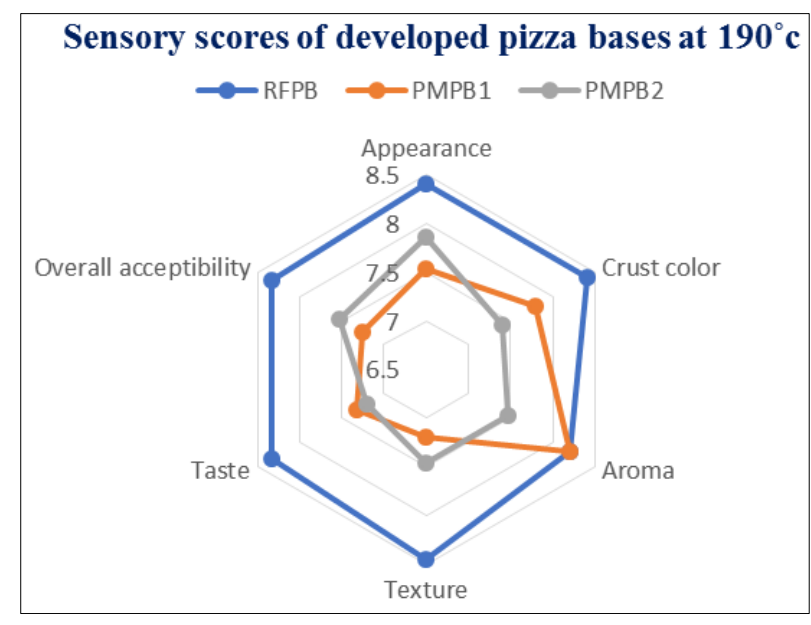

Fig 1.1.1: Sensory scores of developed pizza bases at $190^{\circ} \mathrm{C}$

\section{Sensory evaluation of developed pizza base at $200^{\circ} \mathrm{c}$}

The developed pizza bases PMPB1 of 70:30 proso millet flour and refined wheat flour and PMPB2 of 60:40 proso millet flour and refined wheat flour along with control pizza base (RFPB) was evaluated at $180^{\circ} \mathrm{C}$ for sensory evaluation and represented in the Table 1.1. 
Table 1.1.

\begin{tabular}{|c|c|c|c|c|c|c|}
\hline Pizza base & Appearance & Crust colour & Aroma & Texture & Taste & Overall acceptibility \\
\hline RFPB & $8.46 \pm 0.51^{\mathrm{a}}$ & $8.40 \pm 0.50^{\mathrm{a}}$ & $8.66 \pm 0.48^{\mathrm{a}}$ & $8.66 \pm 0.48^{\mathrm{a}}$ & $8.60 \pm 0.50^{\mathrm{a}}$ & $8.33 \pm 0.48^{\mathrm{a}}$ \\
\hline PMPB1 & $7.53 \pm 0.51^{\mathrm{b}}$ & $8.00 \pm 0.65^{\mathrm{b}}$ & $7.80 \pm 0.56^{\mathrm{b}}$ & $7.86 \pm 0.35^{\mathrm{b}}$ & $8.00 \pm 0.53^{\mathrm{b}}$ & $8.06 \pm 0.45^{\mathrm{a}}$ \\
\hline PMPB2 & $7.06 \pm 0.79^{\mathrm{c}}$ & $7.20 \pm 0.56^{\mathrm{c}}$ & $7.13 \pm 0.63^{\mathrm{c}}$ & $7.26 \pm 0.59^{\mathrm{c}}$ & $7.46 \pm 0.51^{\mathrm{c}}$ & $6.93 \pm 0.45^{\mathrm{b}}$ \\
\hline Mean & $7.38 \pm 0.12$ & $7.43 \pm 0.13$ & $7.51 \pm 0.12$ & $7.58 \pm 0.12$ & $7.70 \pm 0.11$ & $7.33 \pm 0.13$ \\
\hline CD & 0.36 & 0.33 & 0.40 & 0.33 & 0.35 & 0.30 \\
\hline S.E. of mean & 0.17 & 0.16 & 0.20 & 0.16 & 0.17 & 0.15 \\
\hline CV $(\%)$ & 6.67 & 6.05 & 7.39 & 6.07 & 6.23 & 5.71 \\
\hline
\end{tabular}

Note: Values are expressed as mean \pm standard deviation of three determinations.

Means within the same column followed by a common letter do not significantly at $\mathrm{p} \leq 0.05$

RFPB (control): $100 \%$ refined wheat flour pizza base

PMPB 1: $70 \%$ proso millet flour and 30\% refined wheat flour.

PMPB2: $60 \%$ proso millet flour and $40 \%$ refined wheat flour.

The pizza base baked at $200^{\circ} \mathrm{C}$ indicated that the appearance of PMPB1 (7.53 \pm 0.51$)$ was higher than PMPB2 $(7.06 \pm 0.79)$ and lower than RFPB $(8.46 \pm 0.51)$. There was a significant difference $(p<0.05)$ between the sensory scores of appearances for control and developed pizza bases.

The crust color showed that the PMPB1 $(8.00 \pm 0.65)$ was lower than RFPB $(8.40 \pm 0.50)$ higher than PMPB2 (7.20 \pm 0.56$)$. There was significant difference $(p<0.05)$ between. The developed pizza base when assessed for aroma showed that PMPB1 $(7.80 \pm 0.56)$ was higher than PMPB2 $(7.13 \pm 0.63)$ but lower than RFPB $(8.66 \pm 0.48)$. The texture and taste when evaluated indicated that PMPB1 $(7.86 \pm 0.35$ and $8.00 \pm 0.53)$ was lower than the RFPB $(8.66 \pm 0.48$ and $8.60 \pm 0.50)$ but higher than PMPB2 $(7.26 \pm 0.59$ and $7.46 \pm 0.51)$. There was a significant difference $(p<0.05)$ among the developed pizza base and the control for texture and taste.

The overall acceptability of the developed pizza base $(8.06 \pm 0.45)$ was on par with that of RFPB $(8.33 \pm 0.48)$ but contrasting with PMPB2 $(6.93 \pm 0.45)$. The results determined that there was no significant difference between $(p<0.05)$ RFPB and PMPB1.

\section{Sensory evaluation of developed pizza base at $205^{\circ} \mathrm{c}$}

Anu and Anisha, (2016) ${ }^{[1]}$ studied about the sensory quality evaluation for multi grain pizza base incorporating wheat flour, oats, buckwheat along with finger millet and pearl millet in different proportions. The results for crust color of multigrain pizza base (7.3) was relatable with the sensory scores of crust color for developed proso millet pizza base PMPB1 (7.26) baked at $205^{\circ} \mathrm{C}$. The appearance of PMPB1 (7.60 \pm 0.50$)$ was higher than PMPB2 $(6.66 \pm 0.61)$ and contrary with RFPB $(8.26 \pm 0.45)$. There was a significant difference $(p<0.05)$ between developed pizza bases and control. The aroma and texture values for PMPB2 (6.80 and 6.93) was contrasting with the values of RFPB (8.33 and 8.73) and PMPB1 (7.46 and 7.46). The taste of the developed pizza base PMPB1 (7.26 \pm 0.70$)$ was lower than the RFPB $(8.26 \pm 0.59)$ but higher than PMPB2 $(6.93 \pm 0.45)$. There was a significant difference $(p<0.05)$ between control pizza base and developed pizza base for texture and taste.

The overall acceptability of the developed pizza base PMPB1 (7.26 \pm 0.59$)$ which was higher than PMPB2 $(6.86 \pm 0.63)$ but lower than RFPB $(8.33 \pm 0.61)$. There was a significant difference between $(p<0.05)$ control and developed pizza bases.

\section{Conclusion}

Millet based pizza base can be prepared in different proportions by adding proso millet flour along with refined wheat flour as $100 \%$ control, 70:30 ratio of proso millet flour and refined wheat flour (PMPB1) and 60:40 ratio of proso millet flour and refined wheat flour (PMPB2) at different temperatures of $180^{\circ} \mathrm{c}, 190^{\circ} \mathrm{c}, 200^{\circ} \mathrm{c}$ and $205^{\circ} \mathrm{c}$ which will dramatically improve the nutritional and functional characteristics of the developed pizza base.

\section{Acknowledgement}

The authors thank honourable Vice Chancellor of Professor Jayashankar Telangana State Agricultural University, Rajendranagar, Hyderabad for his encouragement.

\section{References}

1. Anu Agarwal, Anisha Verma. Development of multigrains flour pizza base for value addition. International Journal of Advanced Research. 2016; 4(8):1115-1120.

2. Balasubramanian S, Deep N, Yadav, Jaspreet Kaur, Tanupriya Anand. Development and Shelf-life Evaluation of pearl millet based upma dry mix. Journal of Food Science Technology. 2012; 51(6):1110-1117.

3. Giannou V, Kessoglou V, Tzia C. Quality and safety characteristics of bread made from frozen dough. Trends in Food Science and Technology. 2003; 14(3):99-108.

4. Kamaliya KB. Indian bakery industry at a glance in the first decade of the $21^{\text {st }}$ century. Proceedings of International seminar on wheat farm to food- First decade of the new millennium, Banglore, India. Wheat product promotion society, New Delhi, India. 2000, 252-257.

5. Kamaliya KB, Rema S. Nutritional modification of the bakery products. Processed Food Industries. 2003; 7(1):23-27.

6. Meilgaard M, Civille GV, Carr BT. Sensory Evaluation Techniques. $3^{\text {rd }}$. CRC press, Boca Raton, 1999.

7. Preeti Singh, Goyal GK. Functionality of pizza ingredients, British Food Journal. 2011; 113(11):13221338.

8. Rao D, Deepika T. Nutritional comparison of millets, cereals, oats and quinoa. Indian Farming. 2016; 65(12):14-17.

9. Snedecor GW, Cochran WG. Statiscal Methods, Oxford and IBH publishing company, New Delhi, 1983. 